\title{
The Focus of Supervisor Written Feedback to Thesis/Dissertation Students
}

\author{
JOHN BITCHENER* \\ AUT University \\ HELEN BASTURKMEN \\ MARTIN EAST \\ University of Auckland
}

Received: 1 July 2010 / Accepted: 7 October 2010

\begin{abstract}
Written feedback on drafts of a thesis or dissertation is arguably the most important source of input on what is required or expected of thesis-writing students by the academic community. Despite its importance, relatively little is known about what type of information supervisors focus on when giving feedback. This article presents the findings of an exploratory, descriptive study that investigated what supervisors said they focused on when giving feedback. A total of 35 supervisors across three disciplines (Humanities, Sciences/ Mathematics, Commerce) at six New Zealand universities participated in the study. Data were sought from self -report data (written questionnaires and interviews) and samples of feedback given on thesis drafts. The study found that a wide range of beliefs concerning feedback are held by supervisors, that there is little difference in the type of feedback provided by supervisors in the different disciplines and that similar feedback tends to be given to both L1 and L2 students.
\end{abstract}

\section{KEYWORDS:}

thesis/dissertation writing; supervisor feedback; L1 and L2 student writing

\section{RESUMEN}

Aunque los comentarios escritos que se añaden como feedback a los borradores de una tesis o tesina pueden considerarse una de las fuentes de información más importantes sobre lo que se requiere o se espera por parte de la comunidad académica con relación a la expresión escrita utilizada por los estudiantes, se sabe relativamente poco sobre el tipo de información en la que los directores centran su atención a la hora de hacer dichos comentarios. Este artículo presenta los resultados de un estudio exploratorio y descriptivo que investigó los aspectos a los que los directores afirmaron prestar atención al proporcionar comentarios escritos. Un total de 35 directores de tres disciplinas diferentes (Humanidades, Ciencias/Matemáticas, Comercio) pertenecientes a seis universidades de Nueva Zelanda participaron en el estudio. Los datos se obtuvieron a partir de la información proporcionada por los propios participantes (cuestionarios escritos y entrevistas) y de los comentarios escritos en los borradores de algunas tesis. Se halló que los directores sostienen una gran cantidad de opiniones respecto a sus comentarios, que hay pocas diferencias en el tipo de comentarios proporcionados por ellos en las diferentes disciplinas y que los comentarios que se suelen hacer a estudiantes de L1 y L2 tienden a ser similares.

\section{PALABRAS CLAVE}

Redacción de tesis y tesinas, provisión de feedback por el director de tesis, producción escrita de los estudiantes en L1 y L2

\footnotetext{
*Address for correspondence: School of Languages \& Social Sciences, AUT University, Private Bag 92006, Auckland 1020, New Zealand. Telephone: 64 + 9 + 921-9999 ext 7830; Fax: 64 + 9 + 921-9978; e-mail: john.bitchener@aut.ac.nz
} 


\section{INTRODUCTION}

Writing a thesis for the first time is often a challenge for both native (L1) writers and nonnative (L2) writers. Two of the main reasons for this are a limited understanding of the characteristics of the thesis genre and its component parts (for example, part-genres like the introduction and discussion sections/chapters) and uncertainty about the expectations and requirements of their discipline-specific communities of practice. In order to acquaint students with any type of new knowledge, some form of instruction is usually provided. Whereas new knowledge at undergraduate level tends to be provided by means of explicit instruction, this is less often the case at postgraduate level. When students are writing a thesis, 'instruction' is most often provided in the form of written and/or oral feedback by one or more supervisors. Written feedback is given after a student has written a draft text. Oral feedback, on the other hand, can be provided either before or after a student writes a draft text.

Irrespective of the timing of the feedback, the information, critique or advice is provided by the supervisor or supervisory team who is (are) regarded as the 'expert(s)'. The expert's goal is to help the 'novice', the student, come to a level of understanding of what is expected by the academic community. Thus, the importance of the supervisor's role cannot be under-estimated. It is one that needs to be exercised with insight and understanding of what the student needs and finds most effective at the point in time when the feedback is given. Perceptions of what supervisors consider to be appropriate feedback may vary from supervisor to supervisor and from discipline to discipline. Additionally, their perceptions may be further influenced by the L1/L2 status of a student.

Despite a reasonably substantial literature on the types of difficulty that thesis-writing students may experience, very little literature has been published on what supervisors say they give their attention to when providing written feedback. We do not know whether there is a match between the type of feedback they provide, that is, the content focus of their feedback, and the types of difficulty that have been identified in the literature. To help us understand the types of feedback that supervisors say they provide, this article reports on a descriptive study that investigated what supervisors in three different disciplines said were areas they often included in their written feedback. As well as investigating possible disciplinary differences, we were also interested in finding out whether or not the supervisors found there was a need to give L1 and L2 students different types of feedback. Before we present this work, however, we contextualize the study in the following background section.

\section{BACKGROUND}

General writing difficulties experienced by L2 student writers at both undergraduate and postgraduate levels have been the subject of on-going research for more than forty years. 
Much attention has been given to identifying difficulties at the sentence and paragraph levels (Casanave \& Hubbard, 1992; Cooley \& Lewkowicz, 1997; Dong, 1998) but less research has investigated the extent to which these and other difficulties continue to be issues for postgraduate L2 students writing their first thesis in English.

Over the years, several studies have investigated supervisor perceptions of the difficulties that postgraduate L2 students may experience. Casanave and Hubbard's (1992) survey of 85 supervisors across 28 departments at Stanford University reported that L2 doctoral thesis students usually have more problems than L1 writers and that these are more evident at the sentence level (grammatical accuracy and appropriateness, vocabulary appropriateness, spelling and punctuation accuracy) than at the paragraph level. Similar findings have been reported by Cooley and Lewkowicz $(1995,1997)$ in their study of 105 supervisors across nine faculties at the University of Hong Kong. The supervisors in this study explained that while difficulties with surface forms and structures (for example, the use of definite articles and subject-verb agreements) can be irritating, they are less problematic than difficulties affecting the development of coherent ideas and arguments. Dong (1998), in her study of two tertiary institutions in the US, found that L2 postgraduate students experience difficulty with the sequencing and development of propositions and with the use of transitions between propositions and topics. The particular effect of these difficulties on overall communicative success was observed by James (1984) in his case study of a Brazilian PhD student at the University of Manchester. James categorised the effects according to whether they resulted in a breakdown of meaning, a blurring of meaning or a distraction that had little effect on overall meaning. Without exception, the authors of these studies explain that while L2 students may have more difficulty overcoming sentence level difficulties than L1 students, this is not the case when it comes to discourse construction at the paragraph level. L1 students can find argument construction as much of a challenge as L2 students. Also, the literature reveals that L1 and L2 students encounter similar challenges in understanding (1) what characterises the thesis as a particular genre and (2) the discipline-specific requirements and expectations of their supervisors.

Challenges specifically related to an understanding of the generic and discipline-specific characteristics of the thesis genre and its component part-genres (chapters and sections) have been identified to some extent by studies that have investigated supervisor perceptions of thesis-writing student difficulties (Allison, Cooley, Lewkowicz \& Nunan, 1998; Bitchener \& Basturkmen, 2006; Basturkmen \& Bitchener, 2005; Casanave \& Hubbard, 1992; Casanave \& Li, 2008; Dong, 1998; Jenkins, Jordan \& Weiland, 1993; Paltridge \& Starfield, 2007). These publications report that thesis students are often uncertain about what content is appropriate for the separate part-genres of their thesis and about how the content might be most effectively organized. While the structuring and positioning of an argument in relation to the wider literature is particularly challenging for many L1 and L2 students, the literature suggests that L2 students tend to have more difficulty than L1 students when critiquing the 
published research and weighing up the significance of their own research findings (Cadman, 1997; Dong, 1998; Frost, 1999; O’Connell \& Jin, 2001). L2 students who have previously studied in a different epistemological context, where the creation of argument and counterargument and the critical evaluation of published work tend to not be encouraged, are more likely to encounter these challenges. It is clear, therefore, that thesis-writing students need to acquire generic and discipline-specific knowledge and skills if they are to be successfully enculturated into the academic community of researchers and writers.

Knowledge can be acquired in a variety of ways. Typically, in educational settings, some form of explicit instruction is provided. In coursework papers, instruction is packaged so that it can be delivered to large and small groups of students. Thesis-writing students can also benefit from this approach if their programme of study includes the study of coursework papers. However, other thesis-writing students may not have access to this type of instruction. Irrespective of whether they have access to it or not, thesis-writing students are guided or scaffolded by a supervisor or team of supervisors. The provision of feedback is therefore central to the supervisory process as it constitutes a major, if not the major, form of instruction (Benesch, 2000; Hyland, 2005; Hyland \& Tse, 2004; Kumar \& Stracke, 2007).

Various functions of feedback have been proposed in the literature. According to Hyland (2009: 132), feedback helps students understand 'the norms and values of their particular disciplines, and thus facilitates students' enculturation into disciplinary literacies and epistemologies'. As we have mentioned earlier, L2 students writing a thesis often come from a different epistemological background to that into which they are being enculturated. Providing feedback on a one-to-one level, namely, supervisor-supervisee pairings, is one way in which the challenges associated with this can be approached. Other functions of feedback, as Sofoulis (1997:11) explains, include those that help a student 'discover one's own standpoint', 'gain recognition for one's “own work”, and 'find ways of expressing it in one’s "own voice"'. In other words, feedback is important for helping students become independent researchers and writers.

Achieving a level of independence is not something that materializes over night: it is developed over time as supervisors interact with their students and provide feedback on their drafts. A socio-cultural theory of learning (Vygotsky, 1978) provides one useful way of conceptualising the help that thesis students need as they progress towards independence. It suggests that learning is embedded within social situations and occurs as learners interact with people, objects and events in the environment (Kublin, Wetherby, Crais \& Prizant, 1989). Central to this theory of learning is the concept of the Zone of Proximal Development (ZPD). For Vygotsky (1978: 86), the ZPD is 'the distance between the actual developmental level as determined by independent problem solving and the level of potential development as determined through problem solving under adult guidance, or in collaboration with more capable peers'. That is, "through participation in activities that require cognitive and communicative functions, children are drawn into the use of these functions in ways that 
nurture and 'scaffold' them”' (Tharp \& Gallimore, 1988, pp.6-7). Seen from the perspective of socio-cultural theory, a 'master-slave' view of the supervisory relationship (Grant, 2008) albeit a view in which the student will eventually also become a master - is reconceptualised as a more egalitarian 'peer-to-peer' relationship - albeit with the supervisor representing the more capable peer whose role is to scaffold the less capable peer in ways that enable the less capable peer to ultimately reach a higher and independent level. From this perspective, then, supervisor feedback is critical to the development of independence.

Having established the need for supervisor feedback, it is then important to understand the nature and focus of the feedback that supervisors say they give their students. Although, as we noted earlier, a range of studies has identified difficulties that thesis students experience when writing a thesis, there appears to be a gap in the literature when it comes to reporting what supervisors say they actually focus on. Do they provide written feedback on the areas of difficulty reported in the literature? Although there is a small literature base reporting analyses of written feedback (Kumar and Stracke, 2007; San Migual and Nelson, 2007), it is very limited in scope and does not refer to what supervisors say they focus on in their feedback comments. We believe it is important to understand what they say about the focus of the feedback they give as well. The objective of the present study was to determine supervisors' written feedback in relation to:

(a) Content knowledge - its accuracy, completeness and relevance;

(b) Genre knowledge - the functions of different parts of a thesis;

(c) Rhetorical structure and organisation;

(d) Argument development - coherence and cohesion;

(e) Linguistic accuracy and appropriateness

\section{METHODOLOGY}

\subsection{Participants and context}

A total of 35 supervisors across three discipline areas (Humanities, Sciences/Mathematics, Commerce) from six New Zealand universities agreed to take part in the study. There were 17 from Humanities, 11 from Sciences/Mathematics and 7 from Commerce. In each discipline area, we invited 20 supervisors to participate. Of the 35 supervisors who completed a questionnaire, 22 agreed to also be interviewed.

None of the supervisors self identified as an 'L2 supervisor' and over half said that they had supervised students from different L1 backgrounds. All supervisors had a degree of supervisory experience though only a few had been given any formal training in supervision. The training that had been received tended to focus on policy and process followed at each 
supervisor's university rather than on aspects related to the type of feedback that might be helpful for students.

\subsection{Methodological approach}

A multi-method approach to data collection was considered the most appropriate for a study seeking to understand what supervisors say they focus on when providing their thesis students with written feedback on drafts of their thesis (Green, 2001). Their views and practices with regard to feedback were elicited initially from written questionnaire responses and then followed up with more in-depth questioning about the responses through the use of semistructured interviews. The same questions that were asked in the questionnaire provided the structure of the interviews. The interviews also gave us an opportunity to discuss examples of feedback that had been provided by supervisors on pieces of writing drafted by their students. However, not all supervisors were willing to refer to specific textual instances even though ethical protocols had been approved for obtaining student permission.

\subsection{Data collection}

The data collection process at each university was coordinated by one person. In each case, it was a supervisor from a Humanities school or department. The completed questionnaires were collected by each coordinator and sent to the research team. Once the responses had been analysed, the interviews were conducted at each university by one of the research team members using the same interview prompt sheet. During each interview, the feedback samples that the supervisors brought to the meeting were discussed. Those who were not willing to refer to specific examples usually mentioned in general terms the type of example their feedback addressed. The interviewer recorded the interviews and wrote notes under the various interview prompt headings about what was discussed. Particular attention was given to noting page numbers from the sample pieces of writing where illustrations were made.

\subsection{Data analysis}

Distinct response categories were designated from the questionnaire responses given by the supervisors. These were then combined and rationalised to the fewest response categories possible without blurring responses. This information was then tabled. Participant codes were used on the tables, indicating discipline area and allocating each participant a number, so that responses could be tracked. In addition, quoted portions from the responses were entered onto the tables alongside the participant code when the participant's responses were considered to be especially enlightening or when they neatly expressed the key idea of the response 
category. Once all participants' responses had been entered, the number of responses in each category and in each discipline area was calculated.

Similarly with the interviews, the responses were coded according to those established for the questionnaire responses. Occasionally some additional categories emerged as a result of new ideas and practices being mentioned. Frequency of response was calculated and these findings were compared with those from the questionnaire analyses.

\section{RESULTS AND DISCUSSION}

In this section, we present and discuss the findings of the five sections of our research objective: the extent to which supervisors said they provide written feedback on content knowledge, genre knowledge, rhetorical structure and organisation, coherence and cohesion in argument development, and linguistic accuracy and appropriateness. It will be noted that a range of responses was given for each of the five sections (see content elements columns) and that the frequency with which the same response was given by different supervisors is presented both as overall totals and as a total for each discipline. Given the unequal number of supervisors in each discipline, descriptive statistics are presented. Implications and suggestions for further research that should investigate the extent to which all participants agree with or practice what is said in each response category are considered in the conclusion.

\subsection{Feedback on content}

This section focuses on the extent to which supervisors said they need to provide written feedback on the accuracy, completeness and relevance of content presented in thesis drafts (e.g. 'Yes, but what is the evidence for this? Quote pre-test data'). The Table 1 questionnaire responses show that nearly all supervisors (32/35), irrespective of discipline, report that they provide feedback on content.

\begin{tabular}{|l|c|c|c|c|}
\hline \multicolumn{1}{|c|}{$\begin{array}{c}\text { Content } \\
\text { elements }\end{array}$} & $\begin{array}{c}\text { Humanities } \\
\text { (17) }\end{array}$ & $\begin{array}{c}\text { Sciences / } \\
\text { Maths (11) }\end{array}$ & Commerce (7) & Total (35) \\
\hline $\begin{array}{l}\text { Content feedback } \\
\text { given }\end{array}$ & 16 & 9 & 7 & 32 \\
\hline $\begin{array}{l}\text { No content } \\
\text { feedback given }\end{array}$ & 1 & 2 & 0 & 3 \\
\hline $\begin{array}{l}\text { On gaps in } \\
\text { literature }\end{array}$ & 6 & 1 & 3 & 10 \\
\hline On irrelevance & 4 & 0 & 1 & 7 \\
\hline $\begin{array}{l}\text { On wider } \\
\text { significance }\end{array}$ & 1 & 2 & 1 & 4 \\
\hline On arguments & 1 & 2 & 2 & 3 \\
\hline On theory & 1 & 0 & 3 & 4 \\
\hline
\end{tabular}

Table 1. Feedback on content 
Across all three disciplines, feedback on gaps in their students' coverage of the literature was mentioned more frequently than feedback on the other areas identified in the table. However, the extent to which this is mentioned is not high in any of the discipline areas. Less than a third of the supervisors in Humanities and Sciences / Mathematics and an even smaller proportion of those in Commerce mentioned this as an area of focus. This does not mean necessarily that supervisors who did not mention this area of focus do not provide feedback on this.

The interviews were particularly enlightening about the types of gap on which they most frequently comment in the feedback. Across the disciplines and within discipline areas, frequent mention was made of gaps in theoretical understanding and coverage (e.g. identification of the main theoretical threads, an appropriate range of theoretical perspectives including cross-disciplinary perspectives, an inability to relate the theoretical frameworks to the research of the thesis, and gaps in coverage of new literature available in the field). Three supervisors said that it was not so much that students were unaware of the need to identify and discuss the theoretical framework(s) of their research but rather that they were unsure about how to relate it to the other text included in the Introduction and Literature Review chapters of their theses. It is interesting to note that this area of concern tends to not be focussed on in any significant way in the published literature on difficulties that thesis-writing students sometimes encounter.

Commenting on the wider significance of the work ('the big picture') and the need to consider critically what is written were two frequently noted areas in which content feedback was provided by supervisors across the disciplines. Critically evaluating their own work as well as that of others has been reported in the literature as one of the difficulties sometimes experienced by L2 students from different epistemological backgrounds (Cadman, 1997; Dong, 1998; Frost; 1999; O’Connell \& Jin, 2001) so it was not surprising that this was mentioned by several supervisors. If this had been an area of specific focus in the questionnaire, it is likely that more supervisors would have identified it as an area of content often missing from students' texts. The interviews also revealed that students are sometimes reluctant to argue a sufficiently strong case for the findings of their research and so tend to underestimate their significance in light of earlier research. On the other hand, five supervisors said that their students tended to oversell the significance of their findings in light of the big picture. Written feedback was therefore considered crucial for getting this balance right.

Gaps in the justification or explanation of arguments were frequently mentioned by supervisors in the interviews. Difficulties with argument construction have been well reported in the literature (see Cooley \& Lewkowicz, 1995, 1997; Dong, 1998; James, 1984). It was therefore again not surprising to hear this mentioned. This literature base frequently refers to gaps in the argument structure of L2 student texts, including those that leave the reader to make the connection between one proposition and another. As Jenkins et al (1993) explain, 
this difficulty can sometimes result from a lack of clear and logical thinking but as others (e.g. O'Connell \& Jin, 2001) explain, this may also be the result of different training in other epistemological contexts. Whatever the cause, the issue seems to exist. It was highlighted by seven supervisors during the interviews.

Sometimes, supervisors said in the interviews that their students failed to understand some of the key concepts and constructs they were working with but most often this was only a problem in the early stages of the research and writing process. It was not identified as an L2 student issue but as one that needed to be mentioned in written feedback to L1 students as well. Two of these supervisors said that it was not that their students did not understand the concepts/constructs of their field but that they had difficulty with explaining clearly what each meant and referred to because L2 students sometimes have a more limited linguistic repertoire to draw on. They added that this was more likely to be an L2 student difficulty.

Not only did supervisors mention the need to address gaps in their students' drafts but they also said that they had to give written feedback on other issues. Frequent mention was made of the need to draw students' attention to content that should be edited from the thesis (e.g. if students had 'raided material' from others without acknowledgement or inserted too much unqualified personal opinion or presented material that was irrelevant to the topic or argument being developed). A couple of supervisors said that they provided written and oral feedback on content areas on which their students should focus next. While most stressed the importance of giving feedback on their students' draft material, several in Humanities were strongly of the opinion that major written content feedback should not be required if supervisors meet often with their students and discuss the content expectations before their students start writing. None of these issues was referred to as only an L2 student issue.

\subsection{Feedback on part-genres}

This part of our research question focused on whether supervisors reported a need to give genre knowledge feedback on the functions and content of different parts of the thesis. The literature has revealed (see Allison et al., 1998) that across and within disciplines, different practices can be followed with regard to what content is included in different parts of a thesis. Allison et al (1998) identified an overlap between the Introduction and Literature Review chapters and between the Discussion and Conclusion chapters in Applied Linguistics theses and research articles. When asked about whether they provided feedback on what they expected and/ or required in the various part-genres of the thesis, it can be seen from Table 3 that many supervisors across the disciplines (33/35) did so. In particular, a number (11/33) referred to the need to give feedback on the structure and organisation of part-genres and some (8/11) mentioned how they often referred their students to guidebooks/handbooks. There was no observable difference in practice by supervisors from the different disciplines. 
Similarly, it can be seen from Table 2 that eleven supervisors mentioned that no distinction was made when giving part-genre feedback to L1 and L2 students.

\begin{tabular}{|l|c|c|c|c|}
\hline \multicolumn{1}{|c|}{ Part-genre elements } & $\begin{array}{c}\text { Humanities } \\
(\mathbf{1 7})\end{array}$ & $\begin{array}{c}\text { Sciences / } \\
\text { Maths(11) }\end{array}$ & Commerce (7) & Total (35) \\
\hline $\begin{array}{l}\text { 1.Part-genre feedback } \\
\text { given }\end{array}$ & 16 & 10 & 7 & 33 \\
\hline $\begin{array}{l}\text { 2.No part-genre feedback } \\
\text { given }\end{array}$ & 0 & 1 & 3 & 1 \\
\hline 3.On structure & 1 & 1 & 1 & 4 \\
\hline $\begin{array}{l}\text { 4.On purpose of part- } \\
\text { genre }\end{array}$ & 4 & 3 & 0 & 8 \\
\hline $\begin{array}{l}\text { 5.On other } \\
\text { samples/handbooks }\end{array}$ & 1 & 0 & 1 & 1 \\
\hline $\begin{array}{l}\text { 6. On expected word } \\
\text { count }\end{array}$ & 1 & 0 & 0 & 2 \\
\hline $\begin{array}{l}\text { 7.On skills required for } \\
\text { each }\end{array}$ & 7 & 2 & 2 & 1 \\
\hline \begin{tabular}{l} 
8.On part/whole balance \\
\hline 9.Not an L2 issue
\end{tabular} & 0 & 1 & 2 & 11 \\
\hline
\end{tabular}

Table 2. Part-genre requirements/expectations

In the interviews, however, it became clear that content specific to the various partgenres of the thesis was not an area that needed much written feedback if the following steps had been undertaken before students started writing: discuss the requirements and expectations first; give outlines of what goes where; show examples of what is expected (e.g. extracts from sample theses). Two supervisors said it was more likely that part-genre feedback would be given to students who were conducting several studies as part of their thesis. The eight supervisors who spoke in the interviews about the need to provide feedback on partgenre expectations referred mainly to issues with the writing of literature reviews and the methodology and discussion sections. Three supervisors in Sciences and Mathematics explained that the reason this was needed was the uniqueness of a particular piece of research.

Following up on questionnaire responses about the need to provide feedback on structure within part-genres, five supervisors said that they gave feedback about where certain units of content should be placed within a chapter (e.g. topics/themes in the literature review; placement of results; reference to limitations in discussion and conclusion chapters). Six supervisors said that they saw organisational issues more in terms of rhetorical effectiveness (discussed in the next section. Another area that several supervisors referred to was the ongoing need to remind students about the functions of a particular part-genre. Even though discussion and oral feedback occur before and during the writing process, these supervisors mentioned the need to keep on reminding students to think carefully about the purpose behind including particular units of content in a particular part-genre. As one supervisor said, 'some of my students lose sight of the focus of the section they are writing, especially in the 
literature review and discussion chapters'. Many supervisors mentioned that feedback referred their students to other theses and journal articles as good examples of effective writing and appropriate organisation. Two supervisors said that this approach was more effective than directing their students to guidebooks. Referring to the caution issued by Paltridge (2002) and Bitchener and Basturkmen (2006) about the rather general focus of thesis-writing handbooks and guidebooks, these supervisors said they felt that good examples of theses in their discipline area were the most helpful for students and that supervisors would do well to direct their students to specific titles when giving such feedback. We also note the availability now of two useful guides on thesis-writing (Bitchener, 2010; Paltridge \& Starfield, 2007) that refer to the typical discourse moves included in empirically-based theses. Three supervisors in Applied Linguistics mentioned that they had given their students these references in their written feedback.

\subsection{Rhetorical structure/organisation}

In this section of our investigation, we were interested in seeing if supervisors reported providing written feedback on the organisation of content within chapters and sections. Earlier literature (Cadman, 1997; Cooley \& Lewkowicz, 1995, 1997; Dong, 1998) on difficulties encountered by thesis students has noted that difficulties with regard to argument construction continue to be an issue even at postgraduate level. To some extent, this is understandable given the scope of material presented in a thesis. Table 3 shows that most supervisors (31/35), irrespective of discipline, do provide written feedback on the organisation and structure of chapters and sections of their students' theses. Only one supervisor identified this as an L2 student issue.

In particular, written feedback is given about argument construction (13/35). Creating a logical argument was also the overriding concern of those interviewed. Some mentioned a lack of logic in their students' arguments, poor linking of ideas, an absence of transitions, and a failure to integrate tables and quotations into the argument being presented. Six supervisors said in their interviews that L2 students tended to have a little more difficulty than L1 students when it came to fully developing an argument. As one supervisor mentioned, 'some of my L2 students seem to present a series of notes and have trouble linking them together'. The same supervisor said that his written feedback kept on pointing out the need to make sure there is a clear and cohesive link between sentences. Other supervisors mentioned the need to help their L2 students understand how to develop ideas with supportive and counter evidence. It may therefore be, as the earlier literature has suggested (e.g. Cadman, 1997; O’Connell \& Jin, 2001), that L2 students who have studied in other epistemological contexts need more feedback on what is expected. However, argument development was generally seen, in one respect or another, as an issue for both L1 and L2 students. Table 3 also reveals that argument construction was the only concern mentioned by more than one supervisor. 


\begin{tabular}{|l|c|c|c|c|}
\hline $\begin{array}{c}\text { Structure } \\
\text { elements }\end{array}$ & $\begin{array}{c}\text { Humanities } \\
(\mathbf{1 7 )}\end{array}$ & $\begin{array}{c}\text { Sciences / } \\
\text { Maths(11) }\end{array}$ & Commerce (7) & Total (35) \\
\hline $\begin{array}{l}\text { 1.Structure } \\
\text { feedback given }\end{array}$ & 15 & 9 & 7 & 31 \\
\hline $\begin{array}{l}\text { 2.No structure } \\
\text { feedback given }\end{array}$ & 1 & 3 & 4 & 4 \\
\hline $\begin{array}{l}\text { 3.On building a } \\
\text { case or argument }\end{array}$ & 5 & 4 & 0 & 13 \\
\hline $\begin{array}{l}\text { 4.On other } \\
\text { samples }\end{array}$ & 1 & 0 & 0 & 1 \\
\hline 5.On hedging & 1 & 0 & 0 & 1 \\
\hline $\begin{array}{l}\text { 6.On chart } \\
\text { drafting }\end{array}$ & 1 & 0 & 0 & 1 \\
\hline 7.Hands-on & 1 & 0 & 0 & 2 \\
\hline $\begin{array}{l}\text { 8.Avoid bullet } \\
\text { points }\end{array}$ & 1 & 2 & 0 & 1 \\
\hline 9. For oral exam & 0 & 0 & 0 & 1 \\
\hline $\begin{array}{l}\text { 10. An L1/L2 } \\
\text { issue }\end{array}$ & 1 & 0 & 0 & 1 \\
\hline
\end{tabular}

Table 3. Rhetorical structure/organisation

The other responses given in the questionnaire appeared to be issues that only one supervisor considered important. When asked about this, one supervisor said he mentioned the point about avoiding bullet points because he couldn't think of anything else to say and it was something that he had just given feedback on to one of his students. During the interviews, it became clear that some supervisors thought more about organisation and structure when responding to either one or both of the earlier sections in the questionnaire and found it easier not to compartmentalise their thinking about their feedback on content, part-genre expectations and organisation/structure.

\subsection{Feedback on writing coherence and cohesion}

In this section, we focused on whether supervisors reported providing feedback on issues of coherence and cohesion. Difficulties at these levels have been identified in the earlier literature (e.g. Casanave \& Hubbard, 1992; James, 1984) so we were keen to see if supervisors identified these as areas of concern and if they found it necessary to provide written feedback on them. 


\begin{tabular}{|l|c|c|c|c|}
\hline \multicolumn{1}{|c|}{ Elements } & $\begin{array}{c}\text { Humanities } \\
(\mathbf{1 7 )}\end{array}$ & $\begin{array}{c}\text { Sciences / Maths } \\
\mathbf{( 1 1 )}\end{array}$ & Commerce (7) & Total (35) \\
\hline $\begin{array}{l}\text { 1. Feedback } \\
\text { provided }\end{array}$ & 16 & 10 & 6 & 32 \\
\hline $\begin{array}{l}\text { 2. No feedback } \\
\text { provided }\end{array}$ & 0 & 1 & 1 & 1 \\
\hline 3.Section links & 5 & 1 & 0 & 7 \\
\hline 4.Provided once & 1 & 1 & 1 & 2 \\
\hline $\begin{array}{l}\text { 5.Especially for L2 } \\
\text { writers early on }\end{array}$ & 1 & 0 & 2 & 2 \\
\hline $\begin{array}{l}\text { 6.Make it } \\
\text { accessible to } \\
\text { outsider }\end{array}$ & 1 & 0 & 2 & 3 \\
\hline 7.Inconsistent ideas & 1 & 1 & 0 & 1 \\
\hline $\begin{array}{l}\text { 8.Quality of } \\
\text { writing }\end{array}$ & 1 & 0 & 0 & 2 \\
\hline $\begin{array}{l}\text { 9. Focus on } \\
\text { systematic errors }\end{array}$ & 1 & 1 & & 2 \\
\hline
\end{tabular}

Table 4. Coherence and cohesion

Table 4 shows that feedback on these issues was often provided by supervisors (32/35). Particular mention (7/32) was made in the questionnaires to feedback given on the need to link sections of a text. However, the need to give feedback on sectional links was mentioned mainly by Humanities supervisors. Two supervisors explained that feedback was more often given to L2 students and that this occurred most often in early draft writing.

In the interviews, supervisors frequently said that coherence was a problem because there was a lack of clear and sufficient signposting and that they needed to give feedback about ways in which this problem could be overcome. Three supervisors mentioned the value of drawing their students' attention to the use of initial markers; four said that they recommended that their students include more sub-headings; two pointed their students to the use of meta-text, particularly in the form of an advance organiser so that the reader would understand what was about to be discussed.

Other types of feedback referred to in the questionnaire responses were followed up in the interviews. Three supervisors said that inconsistent ideas were sometimes a cause of incoherence, especially if earlier ideas in a text were contradicted later on in a text. Another response in the questionnaires focused on the extent to which the overall quality of writing impacted upon coherence (e.g. ‘So you're saying second language instruction is influenced by the first language? Fine, but perhaps it needs explicit .... stating.'). In the interviews, two supervisors explained that ungrammatical writing often had to be resolved before a student could make a coherent statement. Another supervisor mentioned the tendency amongst some students, both L1 and L2, to use imprecise or vague vocabulary and that this made statements incoherent. Other supervisors mentioned in their interviews how contradictions and going off the track interfered with the coherence of a statement or section. One Humanities supervisor said there was a need to focus feedback on individual sentences because the difficulty her L2 
students had in creating a clear argument was the result of the poor sentential linking. Another supervisor said that he had to deal with 'sprawling and unpunctuated' writing and that there was a need to provide detailed reformulations in the feedback. Although linguistic features were mentioned in the interviews by these supervisors, they were more specifically focussed on in the final section of the study.

\subsection{Feedback on linguistic accuracy and appropriateness}

Anecdotal comments from supervisors often reveal two schools of thought on whether it is the responsibility of supervisors to provide feedback on matters of linguistic accuracy. Some believe that they have a role to play in identifying problematic areas and in drawing their students' attention to these but others are firmly of the view that this is not their role. The literature on linguistic difficulties that thesis-writing students can sometimes experience at the sentence level (Casanave \& Hubbard, 1992; Casanave \& Li, 2008; Cooley \& Lewkovicz, 1995, 1997: Dong, 1998, James, 1984) confirms that there is a need for attention to be given to frequently occurring types of error. We were therefore interested to see if the supervisors reported giving feedback on linguistic errors.

Table 5 on page 93 shows that 33/35 supervisors give linguistic feedback to their students but as some of the questionnaire responses reveal, this does not necessarily mean that they agree with the practice. Six supervisors said in their questionnaire responses that they sometimes reformulate what their students have written (e.g. the student had written 'to bring the meaning of messages' and the supervisor reformulated this as 'to accurately reflect the meaning'). Three Humanities supervisors said they expect their students to sort out their own

accuracy issues. One of these supervisors, in his interview, was adamant that 'we are not editors'. By comparison, three Sciences \& Mathematics and three Commerce supervisors said that they were happy to proofread and correct their students' writing. In discussing this issue, we were interested to see whether much linguistic accuracy feedback was given in the textual examples the supervisors brought to the interviews. Our overwhelming observation was that more feedback was given on matters of linguistic accuracy than on other areas requiring feedback.

When asked about this in the interviews, five supervisors said that they really did not consider the linguistic error identifications and corrections they gave as feedback. As one supervisor put it: 'This is just what we do to make sense of what we are reading. Because more ink is given to these points, does not mean that we are more concerned about grammar than content issues'. While the questionnaire responses did not investigate when accuracy feedback was given, the interviews discussions did. Nine supervisors said that linguistic feedback is most often provided in the early and late stages of the supervisory process. One supervisor explained, 'I give feedback on accuracy on early drafts because I want to set the standard and I do the same again at the end when I am helping my students polish up the 
writing before examination'. On the other hand, four supervisors said it was a recurrent task even though they did not like doing it.

When it came to matters of style and appropriateness of vocabulary choice and academic register, more supervisors were prepared to focus their attention on this even though only four supervisors mentioned this in their questionnaire responses. In the interviews, seven supervisors said that they found a need to provide feedback on stance because there was a tendency for students to either overstate or understate the significance of earlier research findings and their own findings. Four supervisors said that their feedback focused on the importance of hedging. Referring to overstatements, one said that 'huge claims are not hedged in light of the literature' and in referring to understatements, the same supervisor said the 'interpretation of results from statistics can be too tentative'. With regard to the use of an appropriate academic register, three supervisors said that they needed to tell their students not to use 'such colourful description'.

\begin{tabular}{|c|c|c|c|c|}
\hline Elements & $\begin{array}{c}\text { Humanities } \\
\text { (17) }\end{array}$ & $\begin{array}{c}\text { Sciences / Maths } \\
\text { (11) }\end{array}$ & Commerce (7) & Total (35) \\
\hline $\begin{array}{l}\text { 1. Linguistic } \\
\text { feedback given }\end{array}$ & 15 & 11 & 7 & 33 \\
\hline $\begin{array}{l}\text { 2. No linguistic } \\
\text { feedback given }\end{array}$ & 0 & 0 & 0 & 0 \\
\hline $\begin{array}{l}\text { 3. On voice \& } \\
\text { stance }\end{array}$ & 6 & 4 & 1 & 11 \\
\hline 4. On style & 3 & 1 & 0 & 4 \\
\hline $\begin{array}{l}\text { 5. Provide } \\
\text { reformulation }\end{array}$ & 2 & 3 & 1 & 6 \\
\hline $\begin{array}{l}\text { 6. Expect student to } \\
\text { sort accuracy }\end{array}$ & 3 & 0 & 0 & 3 \\
\hline $\begin{array}{l}\text { 7. Feedback if } \\
\text { persistent \& } \\
\text { multiple problems }\end{array}$ & 3 & 0 & 0 & 3 \\
\hline $\begin{array}{l}\text { 8. Micro correction } \\
\text { leads to macro in } \\
\text { discussion }\end{array}$ & 1 & 0 & 0 & 1 \\
\hline $\begin{array}{l}\text { 9. Proofreading } \\
\text { provided }\end{array}$ & 0 & 3 & 3 & 6 \\
\hline
\end{tabular}

Table 5. Linguistic accuracy and appropriateness

\section{CONCLUSION}

The aim of this article was to report the findings of part of a wider study that investigated what supervisors and students considered to be effective feedback on drafts of a thesis written in English. The focus of this article was on what supervisors in three discipline areas said they give their attention to when providing written feedback on thesis drafts to L1 and L2 students. 
Data from questionnaire and interview responses, together with examples of feedback from samples discussed in the interviews, elicited whether feedback was given on (1) the accuracy, completeness and relevance of the content included in the draft, (2) what was required and expected for each part-genre of the thesis, (3) the rhetorical structure and organisation of the discourse, (4) the coherence and cohesion of the arguments presented and (5) the linguistic accuracy and appropriateness of the drafts.

The most frequently mentioned area of content that required supervisor feedback was gaps in the content covered, especially with regard to theoretical understanding and coverage. Supervisors across the disciplines drew attention to this issue and explained that it was an area that both L1 and L2 students tended to struggle with. On the other hand, they said that there was a greater need to give feedback to L2 students on the importance of discussing the published literature and their own research findings in light of 'the big picture' and of taking a critical look at what is published. Argument construction was identified by supervisors in each discipline as an area in which both L1 and L2 students often needed feedback, especially with early drafts of a chapter or section. Providing sufficient argument and presenting it in a coherent and cohesive manner were identified as key areas for supervisor attention.

While some supervisors said in the interviews that they usually did not need to give written feedback on part-genre expectations if they discussed what was expected before their students started writing, most supervisors said that they needed to give feedback on ways to most effectively structure the content their students had included. Part-genre feedback was not seen as only an L2 student issue. However, feedback on linguistic accuracy was seen as more of an L2 student issue and textual examples of feedback discussed in the interviews revealed that more feedback was given on accuracy and appropriateness than on any other area of feedback provided. Nevertheless, several supervisors explained that they did not consider this type of text marking to be feedback. They saw it more as editorial marking and did not want the attention of their students to be drawn away from their more macro issue comments. Overall, it seems clear that the issues identified earlier in the literature as potentially problematic ones for $\mathrm{L} 2$ thesis writers are those that supervisors say they provide written feedback on.

The extent to which supervisors provide these different types of feedback to their students is not something that this study focussed on. The aim of this study was to elicit, by means of supervisor self-report data, the areas on which they said they found it necessary to give feedback. The tabled results show the range of feedback areas on which they often commented. Further research would do well to quantify these response categories so that we understand the extent to which they are areas that supervisors say they are the foci of their attention.

It can be seen that supervisors do see a need to provide written feedback on many of the areas identified in the literature referred to above. They provide feedback on linguistic issues at the sentence level, discourse feedback at the paragraph level, and feedback on what is 
expected and required for the different part-genres of a thesis. In providing written feedback, supervisors can be seen to play the expert role as they seek to help their students become more independent of them and reach the level of performance expected by their academic communities. However, this is only one aspect of the relationship identified in socio-cultural theory. Supervisors see this role as an important part of the dialogic relationship they have with their students. This role is equally important for both L1 and L2 thesis students, even though L2 students may sometimes require feedback in areas that L1 students do not require. That said, it should nevertheless be noted, as the literature referred to above points out, that the issues to which supervisors draw their L2 students attention are often less critical than those on which both L1 and L2 students receive feedback.

Inevitably, empirical investigations are characterised by a number of limitations. In identifying some of these with regard to this study, we are, at the same time, confident that the findings of the study have not been seriously affected by any of these. First, the data for the analysis comprised drafts at various stages of the research process. Some were from 'early' work and some from 'nearly completed' theses. Further research is needed to compare the nature of feedback given at early and later stages of the supervision process. It is possible that what supervisors comment on and how they frame their comments may change over time.

Second, the sample size in two of the discipline areas was rather modest, and students from the Humanities discipline were more heavily represented than those from the other two disciplines. This limits the amount of cross-disciplinary comparison that can be made and is likely to skew findings in the direction of the types of feedback more normatively given to students in the Humanities. Future research should therefore aim for a more balanced representation across discipline areas.

Third, using open-ended questions in the questionnaire required participants both to interpret the meanings of questions and to give time to answering them. There was no opportunity to revisit the questionnaire or to seek clarification in cases where subsequent interviews did not occur. Future research might use the findings of this study to develop a closed-ended questionnaire that includes a series of behavioural and attitudinal statements requiring Likert-scale responses and ranking. This method of data collection would enable a quantitative analysis of feedback priorities and take the findings of this study to a new level.

\section{ACKNOWLEDGEMENTS}

The authors would like to thank Ako Aotearoa New Zealand for funding the project presented in this article and Dr Heather Meyer for the time and expertise she brought to the project as research assistant. 


\section{REFERENCES}

Allison, D., Cooley, L., Lewkowicz, J., \& Nunan, D. (1998). Dissertation writing in action: The development of a dissertation writing support program for ESL graduate research students. English for Specific Purposes, 17, 199-217.

Basturkmen, H., \& Bitchener, J. (2005). The text and beyond: Exploring the expectations of the academic community for the discussion of results section of Masters theses. New Zealand Studies in Applied Linguistics, 11(1), 1-20

Benesch, S. (2000). Critical English for Academic Purposes: Theory, Politics and Practice. Mahwah: Lawrence Erlbaum.

Bitchener, J. (2010). Writing an Applied Linguistics thesis or dissertation: A guide to presenting empirical research. Basingstoke, Hampshire: Palgrave Macmillan.

Bitchener, J., \& Basturkmen, H. (2006). Perceptions of the difficulties of postgraduate L2 thesis students writing the discussion section.Journal of English for Academic Purposes, 5, 4-18.

Cadman, K. (1997). Thesis writing for international students: A question of identity. English for Specific Purposes, 16, 3-14.

Casanave, C., \& Hubbard, P. (1992). The writing assignments and writing problems of doctoral students: Faculty perceptions, pedagogical issues, and needed research. English for Specific Purposes, 11, 33-49.

Casanave, C., \& Li, X. (Eds.). (2008). Learning the literacy practices of graduate school: Insiders' reflections on academic enculturation. Ann Arbor, MI: The University of Michigan Press.

Cooley, L., \& Lewkowicz, J. (1995). The writing needs of graduate students at the University of Hong Kong: A project report. Hong Kong papers in Linguistics and Language Teaching, 18, 121-123.

Cooley, L., \& Lewkowicz, J. (1997). Developing awareness of the rhetorical and linguistic conventions of writing a thesis in English: Addressing the needs of ESL/EFL postgraduate students. In A. Duszak (Ed.), Culture and styles of academic discourse (pp.113-140). Berlin: Mouton de Gruyter.

Dong, Y. (1998). Non-native graduate students' thesis/dissertation writing in science: Self-reports by students and their advisors from two US institutions. English for Specific Purposes, 17, 369390.

Frost, A. (1999). Supervision of NESB postgraduate students in science-based disciplines. In Y. Ryan, \& O. Zuber-Skerritt (Eds.), Supervising postgraduates from non-English speaking backgrounds (pp. 101-109). Birmingham, UK: Open University Press.

Grant, B. (2008). Agonistic struggle: Master-slave dialogues in humanities supervision. Arts and Humanities in Higher Education, 7 (1), 9-27.

Greene, J. (2001). Mixing social inquiry methodologies. In V. Richardson (Ed.), Handbook of research on teaching.Washington DC: American Educational Research Association.

Hyland, K. (2009). Academic Discourse. London: Continuum.

Hyland, K. \& Tse, P. (2004). Metadiscourse in academic writing: A reappraisal. Applied Linguistics, 25(2), 156-177.

James, K. (1984). The writing of theses by speakers of English as a foreign language: A case study. In R. Williams, J. Swales, \& J. Kirkman (Eds.), Common ground: Shared interests in ESP and communication studies, ELT documents 117 (pp.99-113). Oxford: Pergamon Press.

Jenkins, S., Jordan, M., \& Weiland, P. (1993). The role of writing in graduate engineering education: A survey of faculty beliefs and practices. English for Specific Purposes, 12, 51-67.

Kublin, K., Wetherby, A., Crais, E., \& Prizant, B. (1989). Prelinguistic dynamic assessment: A transactional perspective. In A. Wetherby, S. Warren, \& J. Reichie (Eds.), Transitions in prelinguistic communication (pp.285-312). Baltimore, MD: Paul H. Brookes.

Kumar, V. \& Stracke, E. (2007). An analysis of written feedback on a PhD thesis. Teaching in Higher Education, 12:4, 461-470.

O’Connell, F., \& Jin, L. (2001). A structural model of literature review: An analysis of Chinese postgraduate students' writing. Paper presented at BALEAP Conference, Sheffield Hallum University, Sheffield, UK.

Paltridge, B. (2002). Thesis and dissertation writing: An examination of published advice and actual practice. English for Specific Purposes, 21 (2), 125-143. 
Paltridge, B., \& Starfield, S. (2007). Thesis and dissertation writing in a second language: A handbook for supervisors. New York: Routledge.

San Migual, C.\&C.D. Nelson, (2007). Key writing challenges of practice-based doctorates. Journal of English for Academic Purposes,6:1, 71-86.

Sofoulis, Z. (1997). What scholar would endorse me? Transference, counter-transference and postgraduate pedagogy. Paper presented 3 October 1997 to the School of Education, the University of Auckland: Unpublished.

Tharp, R., \& Gallimore, R. (1988). Rousing minds to life: Teaching, learning, and schooling in social context. Cambridge, UK: Cambridge University Press.

Vygotsky, L. (1978). Mind in society: The development of higher psychological processes. Cambridge, MA: Harvard University Press. 